Pregledni rad

https://doi.org/10.31784/zvr.8.1.9

Datum primitka rada: 2. 12. 2019.

Datum prihvaćanja rada: 27. 1.2020.

\title{
ZADOVOLJSTVO MLADIH KORISNIKA USLUGAMA PAKETNIH DOSTAVLJAČA U REPUBLICI HRVATSKOJ
}

\author{
Dora Naletina \\ Dr. sc., docent, Ekonomski fakultet, Trg J. F. Kennedy 6, 10000 Zagreb, Hrvatska; \\ e-mail: dora.naletina@efzg.hr \\ Mate Damić \\ Dr. sc., docent, Ekonomski fakultet, Trg J. F. Kennedy 6, 10000 Zagreb, Hrvatska; \\ e-mail:mdamic@efzg.hr

\section{Luka Meštrović} \\ Mag. oec., PBZ d. d., Radnička 45, 10000 Zagreb, Hrvatska; e-mail: luka.mestrovic@yahoo.com
}

\section{SAŽETAK}

Posljednjih godina, uloga paketne dostave u urbanim područjima kontinuirano raste, prvenstveno zbog ubrzanog rasta online kupovine, a navedeno nije zaobišlo niti hrvatsko tržište. Pristupanjem Hrvatske Europskoj uniji, tržište poštanskih usluga se liberaliziralo te su se stvorili preduvjetiza proširenje postojeće ponude usluga, porast konkurencije kao i povećanje količine prenesenih paketa. Na tržištu paketne distribucije u Republici Hrvatskoj djeluju gotovo svi svjetski poznati pružatelji usluga. Uzevši u obzir kako upravo mladi korisnici u najvećoj mjeri koriste informacijske tehnologije, a samim time i kupovinu putem iste, nameće se potreba istraživanja njihova zadovoljstva kvalitetom usluga paketnih dostavljača na području Republike Hrvatske. Cilj ovog rada je, na temelju provedenog primarnog istraživanja, ispitati zadovoljstvo mladih korisnika uslugama paketnih dostavljača u Republici Hrvatskoj. Pouzdanost usluge i poštivanje roka dostave potvrđeni su kao najvažniji čimbenici koji determiniraju zadovoljstvo mladog korisnika kvalitetom cjelokupne usluge. Ispitanici su kao najmanje važno istaknuli prepoznatljivost imena poduzeća koje im pruža usluge paketne distribucije. Poduzeća koja posluju na ovom tržištu moraju poboljšati dostupnost informacija, brzinu i sigurnost dostave paketa, ali i ulagati u daljnju modernizaciju.

Ključne riječi: Hrvatska, mladi korisnici, paketna pošiljka, paketna dostava

\section{UVOD}

Paketna distribucija postaje sve prisutnija u svakodnevnom životu. Promjene na tržǐ̌tu poštanskih usluga javljaju se uslijed završetka liberalizacijskog procesa u zemljama članicama, napretka tehnologije, ali i ubrzanog rasta online kupovine. Nije samo poslovanje poduzeća na ovom tržištu 
determinirano ubrzanim rastom online trgovine, već i poslovanje poduzeća na ostalim tržǐšima (Vakulenko et al., 2018). Obzirom da raste i broj konkurenata na tržištu, postaje komplicirano organizirati distribuciju paketa u što kraćem roku, a uz što veću kvalitetu usluge koju zahtijevaju krajnji korisnici. Digitalizacija je utjecala na značajno smanjenje obujma pisama koji se distribuiraju, odnosno, u 2018. godini zabilježen je 7\% manji volumen u odnosu na godinu ranije. Stoga se poštanski operatori, kako bi opstali i spriječili daljnji pad prihoda, moraju prilagoditi ubrzanim promjenama u okruženju (Finnish Transport and Communications Agency, 25.06.2019.).

Obzirom kako mladi korisnici u najvećoj mjeri koriste informacijske tehnologije, kao i kupovinu putem iste, nameće se potreba istraživanja njihova zadovoljstva kvalitetom usluga paketnih dostavljača na području Republike Hrvatske. Cilj ovog rada je provesti primarno istraživanje zadovoljstva mladih korisnika kvalitetom usluga paketnih dostavljača u Republici Hrvatskoj, a kako bi se utvrdilo trenutno zadovoljstvo mladih korisnika stanjem na tržištu distribucije paketa u Republici Hrvatskoj. Time bi se istaknule postojeće prednosti i nedostaci kao i preporuke za bolji razvoj tržišta distribucije paketa u svrhu pružanja većeg zadovoljstva krajnjim korisnicima.

Nakon uvodnog dijela, u drugom poglavlju pobliže se objašnjava paketna distribucija, definiraju se ključni pojmovi i karakteristike, ali se analiziraju i sudionici na promatranom tržištu. Kao uvod u provedeno primarno istraživanje, daje se pregled postojećih istraživanja, a potom se objašnjava metodologija istraživanja, rezultati te ograničenja, kao i preporuke za buduća istraživanja.

\section{OPĆENITO O PAKETNOJ DISTRIBUCIJI}

Prvenstveno zahvaljujući kupovini putem interneta na koju se odlučuje sve veći broj osoba, paketna distribucija postaje sve zastupljenija u svakodnevnom životu ljudi. Tako su pružatelji usluga na ovom tržištu, s jedne strane, suočeni s distribucijom sve većeg broja paketa, dok s druge strane korisnici iz dana u dan imaju sve veće zahtjeve glede brzine i kvalitete pružene usluge. Stoga se u nastavku ovog poglavlja daje definicija paketne distribucije i karakteristike iste, a potom se analiziraju i sudionici ovog tržišta.

\section{1 Definiranje i karakteristike paketne distribucije}

Paketna distribucija je djelatnost koja se odnosi na distribuciju roba u paketnom obliku (Bendeković i Batarelo, 2009: 79). Zadatak politike distribucije mora biti prvenstveno omogućiti redovitu te pravodobnu nabavu proizvoda nekog poduzeća, te sukladno navedenom, najpovoljnije osiguravanje prisutnosti na tržištu. Važnost distribucije ogleda se upravo u činjenici da postojanje potražnje za robom nije dovoljno već je iznimno bitno da ta roba određenim kanalima dođe do krajnjih korisnika. Andrijanić (1999: 31). Isporuka robe u obliku paketa najčešće podrazumijeva isporuku komadne pošiljke u određenom obliku i pakiranju, a koji ovise o traženom načinu isporuke, odnosno prijevoznom sredstvu i brzini isporuke. O uvjetima isporuke koje zahtijeva korisnik ovise i ostali bitni čimbenici poput načina preuzimanja, manipulacije i isporuke pošiljke, ali i visina naknade za obavljeni posao isporuke (Bendeković i Batarelo, 2009: 80).

Prema Zakonu o poštanskim uslugama (Narodne novine, 144/12): 
- Paket podrazumijeva poštansku pošiljku koja sadrži robu i predmete;

- Poštanska usluga je usluga koja uključuje svako postupanje s poštanskim pošiljkama od strane davatelja poštanskih usluga, a osobito prijam, usmjeravanje, prijenos i uručenje poštanskih pošiljaka u unutarnjem ili međunarodnom poštanskom prometu. Poštanske usluge obuhvaćaju univerzalnu uslugu, zamjenske poštanske usluge i ostale poštanske usluge.

- Univerzalna usluga je skup poštanskih usluga koje su dostupne svim korisnicima poštanskih usluga na cijelom području Republike Hrvatske po pristupačnoj cijeni. Zamjenske poštanske usluge su poštanske usluge koje mogu odstupati od uvjeta univerzalne usluge, kao što su obveza dnevne dostave ili obavljanje usluga na cijelom području države, no sa stajalista korisnika mogu se smatrati uslugama unutar opsega univerzalne usluge, jer su u dostatnoj mjeri zamjenjive univerzalnom uslugom. Ostale poštanske usluge se odnose na usluge prijma, usmjeravanja, prijenosa i uručenja poštanskih pošiljaka, u unutarnjem i međunarodnom prometu, koje nisu obuhvaćene univerzalnom uslugom ili zamjenskim poštanskim uslugama. Dopunske poštanske usluge su usluge koje sadrže poseban način postupanja tijekom prijma, usmjeravanja, prijenosa i uručenja pošiljaka kod obavljanja poštanskih usluga.

Poštanske pošiljke su pismovne pošiljke, paketi, preporučene pošiljke, pošiljke s označenom vrijednosti, sekogrami, izravna pošta i tiskanice (NN, 37/10).

Industrija poštanskih usluga koja uključuje paketnu distribuciju igra važnu ulogu u gospodarskom i društvenom razvoju mnogih država (Kollara, 2017: 10). Sam proces paketne distribucije te broj sudionika $u$ istoj ovisi u prvom redu o tome koji model distribucije određeno poduzeće primjenjuje, a u literaturi se ističu ambulantna distribucija (kapilarna ili direktna distribucija) i centralna distribucija. Kod ambulantne distribucije proizvođači sami prodaju vlastite proizvode krajnjim korisnicima dok centralna distribucija podrazumijeva distribuciju roba preko jednog ili manjeg broja skladišta, nakon čega slijedi daljnja distribucija robe prema maloprodajnim mjestima. Bitna karakteristika ambulante distribucije je da se pošiljka distribuira direktno primatelju bez posrednika (Dujak, 2012). Usluge paketne distribucije su bitne za zadovoljenje potreba brojnih industrija. Bilo da se radi o bankama, osiguravajućim društvima, državnim institucijama ili bilo kojem drugom poduzeću. I javni i privatni korisnici oslanjali su se i oslanjaju se i danas na poštanske usluge za razmjenu informacija, dokumenata, paketa ili pisama (Hillebrand et al., 2016:3).

\section{2 Sudionici u procesu paketne distribucije}

Svi sudionici u procesu paketne distribucije trebali bi međusobno koordinirati svoje aktivnosti jer upravo o njima ovisi koliko će na kraju biti uspješan cijeli proces. Sudionici u poslovanju međunarodne paketne distribucije su svi subjekti koji na bilo koji način sudjeluju u procesu međunarodne paketne distribucije od trenutka davanja naloga za slanje do isporuke pošiljke, a u pravilu se razlikuju (Bendeković i Batarelo, 2009: 81): 
- direktni sudionici (korisnik usluga). Korisnik usluga može biti poduzeće, institucija ili osoba koja želi koristiti uslugu nacionalne ili međunarodne paketne distribucije zbog nekog svog poslovnog ili osobnog interesa.

- poduzeće za paketnu distribuciju. Isto logistikom koju pruža ili suradnjom s međunarodnim partnerima omogućuje uspješnu realizaciju procesa distribucije.

- transportne organizacije koje sudjeluju u procesu distribucije, a sudjeluju u procesu u slučajevima kada poduzeće koje se bavi paketnom distribucijom nema organiziranu vlastitu transportnu mrežu u određenim dijelovima svijeta ili kada je njihovo korištenje neizbježno s obzirom na udaljenosti i vrstu transporta koja se zahtijeva. Na tržištu distribucije paketa nužno je osvijestiti poduzeća kako je posjedovanje vlastitog voznog parka skupo te se što više trebaju oslanjati na outsourcing, odnosno, trebaju sklopiti ugovor o suradnji s transportnim poduzećem. Navedeno omogućuje poduzećima da se više posvete svojoj temeljnoj djelatnosti i u konačnici ostvare puno bolje poslovne rezultate (Jackson, 01.05.2008.)

- državne institucije vezane za distribuciju i transport robe bitan su i nezaobilazan sudionik u procesu paketne distribucije, a propisima i postupcima nastoje uspostaviti jednaka pravila kao u zemljama i regijama u okruženju. Uloga državnih institucija je iznimno velika obzirom da je Hrvatska učlanjenjem u Europsku uniju pristupila zajedničkom tržištu univerzalnih poštanskih domaćih i prekograničnih usluga. Iste moraju osigurati da cijena isporuke univerzalnih usluga zadovoljava standarde prema troškovnoj usmjerenosti (Ministarstvo pomorstva, prometa i infrastrukture, 2014: 20).

Važno je spomenuti i centre za sortiranje u kojima se prikuplja roba s različitih lokacija te se potom sortira ovisno o mjestu narudžbe, konsolidira te otprema prema krajnjem korisniku. Poštanski operatori moraju izabrati hoće li imati nekoliko većih centara za sortiranje ili će imati više malih centara za sortiranje. Ukoliko se odluče na nekoliko većih sortirnih centara, tada se radi o uspostavi centralizirane prometne mreže te su prijevozne rute duže. $U$ slučaju uspostave velikog broja malih sortirnih centara radi se o uspostavi decentralizirane prometne mreže (Kollara, 2017: 13).

Osnovni cilj poduzeća koje se bavi paketnom distribucijom je u što kraćem vremenu i uz minimalne troškove dostaviti paket i tako osigurati zadovoljstvo svih sudionika u procesu. Pošiljatelj i primatelj će biti zadovoljniji što je dostava bila brža, dok će se ostali sudionici u ovom distribucijskom procesu zadovoljiti s naknadom za obavljene usluge (Kollara, 2017: 36).

\section{ISTRAŽIVANJE ZADOVOLJSTVA MLADIH KORISNIKA KVALITETOM USLUGA PAKETNIH DOSTAVLJAČA U REPUBLICI HRVATSKOJ}

U nastavku ovog poglavlja prvo se daje pregled izabranih istraživanja koja su u fokusu imala tržište poštanskih usluga, potom se objašnjava metodologija istraživanja, analiziraju dobiveni rezultati i ističu ograničenja provedenog istraživanja. 


\section{1 Pregled postojećih istraživanja}

Kristensen i suradnici (2000) istražuju zadovoljstvo potrošača uslugama pošte u Danskoj, te koriste metodologiju Europskog indeksa zadovoljstva potrošača. Poseban naglasak stavljen je na ideju kombiniranja generičkih mjerenja zadovoljstva kupaca sa specifičnim mjerenjima Danske pošte. Rezultati su pokazali kako je utjecaj imidža znatno slabiji na poslovnom tržištu nego li na tržištu privatnih korisnika, dok s druge strane utjecaj interakcije s kupcima ima znatno veći utjecaj na tržištu poslovnih korisnika nego na tržištu privatnih korisnika.

Li i suradnici (2006) proveli su istraživanje u svrhu usporedbe zadovoljstva kupaca vodećim američkim poduzećima koja se bave distribucijom paketa, UPS-om i FedEx-om. Uspoređivalo se cjelokupno zadovoljstvo kupaca na temelju pet kritičnih čimbenika (dostupnost, odaziv, pouzdanost, potpunost i profesionalnost usluge) koji izravno utječu na zadovoljstvo kupaca u djelatnosti distribucije paketa, te posljedično i na dva promatrana poduzeća koja se bave distribucijom paketa. Uzimajući u obzir dolaznu i odlaznu poštu, rezultati su pokazali kako ne postoje značajne razlike u rangiranju kvalitete usluge između dva analizirana poduzeća. Rezultati istraživanja sugeriraju kako sličnost u ocjeni kvalitete usluge ova dva poduzeća proizlazi i dijelom kao posljedica dominantne pozicije istih u paketnoj industriji. Bitno je istaknuti kako cijena usluge dostave pošiljaka nije bila uključena $u$ istraživanje, a smatra se bitnim faktorom prilikom odabira poduzeća za isporuku paketa.

Seitz i suradnici (2008) nastojali su utvrditi mjerila koja se koriste prilikom odabira malih paketnih transportnih poduzeća, uz određivanje razina važnosti po kriterijima. Najizraženiji kriterij ocjenjivanja koji su koristili ispitanici je realizacija dostave na vrijeme. Doplate su bile najmanje važan kriterij pri odabiru malog paketnog prijevoznika. lako je vrijeme isporuke rangirano najviše u svim funkcijama, uredski menadžeri ih svrstavaju na drugo mjesto, odnosno, poslije razine cijena. Dostava proizvoda postala je više od puke robne usluge te stoga odabir malog paketnog transportnog poduzeća ovisi o brzini i točnosti isporuke, ali i o odnosu između cijena i razine usluge.

Kujačić i suradnici (2009) analiziraju model održivosti univerzalnog poštanskog servisa, a u svrhu definiranja prijedloga novog modela održivosti univerzalnog poštanskog servisa kako bi se povećala efikasnost nacionalnog poštanskog operatora u Srbiji. Naglašava se potreba osiguranja dodatnih prihoda za nacionalnog operatora u Srbiji i to kroz pružanje novih usluga, ali i potreba liberalizacije dijela tržišta za koje je procijenjeno kako bi ulazak novih poduzeća pozitivno utjecao na kvalitetu i cijenu usluge koju pruža nacionalni poštanski operator.

Peković i Tričković (2010) provode istraživanje u Srbiji u svrhu modeliranja optimalnog rasporeda jedinica poštanske mreže, a u cilju poboljšanja logističkih performansi poštanskih sistema. Ističu kako bi se modeliranje poštanske mreže trebalo raditi na osnovi resursa kojima državna uprava, lokalna samouprava i pošta raspolažu, kao i na temelju očekivanih koristi za određeno područje. Prilikom izbora modela treba voditi računa o broju i strukturi zaposlenih u državnoj upravi i lokalnoj samoupravi, načinu pribavljanja sredstava te iskorištenosti kapaciteta i obujma usluga državne administracije. Proces modeliranja zapravo je zajednički poduhvat javnog operatora te državne uprave, ali i lokalne samouprave. 
Liu i Wen (2012) analiziraju konkurentnost na slučaju DHL-a te postavljaju dva istraživačka pitanja: 1. Koje konkurentske prednosti DHL dobiva od vanjskih i unutarnjih čimbenika. 2. Koji nedostatak posjeduje DHL u odnosu na konkurente? Što DHL može naučiti analizirajući nedostatke u konkurentnosti? Primarni podaci za ovo istraživanje prikupljeni su uglavnom putem intervjua dok su službena izvješća korištena kao izvori sekundarnih podataka. Obzirom na vanjske i unutarnje čimbenike DHL-a, vrši se implikacija SWOT analize koja pokazuje da snaga DHL-a proizlazi iz zadovoljstva kupaca. Slabosti su cijena te osiguranje od odgovornosti. Mogućnosti su razvoj suradnje te primjena i razvoj inovacija. Prijetnje proizlaze iz izrazite konkurentnosti. Snaga i mogućnosti smatraju se izvorom kompetitivne prednosti DHL-a, dok slabost i prijetnje predstavljaju konkurentske slabosti te treba raditi na njima (Liu i Wen, 2012). Šarac i Jovanović (2012) analiziraju aktualno stanje kvalitete poštanskih usluga s aspekta korisnika, a u svrhu identificiranja potencijala za njihovo unapređenje. Primijenjen je Servqual model s ciljem prepoznavanja nedostataka trenutne realizacije poštanskih usluga. Rezultati istraživanja pokazali su kako korisnici očekuju više u pogledu poštanskih usluga po svim promatranim dimenzijama (pouzdanost, sigurnost, opipljivost, empatija, sposobnost). Primijenjeni model je pokazao kako na prvom mjestu pozornost treba posvetiti dimenziji sigurnosti te da treba znatno poraditi i na ljubaznosti zaposlenika. Potrebno je raditi na razvijanju i podržavanju adekvatne kulture usluživanja korisnika obzirom da se treba uspostaviti usklađenost između kvalitete zaposlenika i zahtjeva korisnika.

Dobrodolac i suradnici (2013) u svom radu analiziraju mogućnosti za unapređenje univerzalne poštanske usluge i to sa stajališta korisnika, ali i efikasnosti poslovanja poštanskog sustava. Istraživanje je provedeno nad uzorkom od 26 javnih poštanskih operatora iz Europe. Predlaže se uvođenje novog koncepta u kojem bi prvo pošiljatelj specificirao rok za isporuku i u kojem se ostvareni rezultati javnog operatora ne bi mjerili na globalnom nivou već prema potrebama korisnika. Uvođenje novog koncepta usluga omogućilo bi unapređenje organizacije dostave kod javnog poštanskog operatora (Dobrodolac et al., 2013: 207-211). Gligorić i Đumić (2013) provode istraživanje elemenata netržišnog poslovnog okruženja na tržištu poštanskih usluga u Srbiji. Cilj rada je pokazati kako tradicionalne poštanske usluge ne zadovoljavaju gotovo niti jedan uvjet koji klasična ekonomska teorija zahtijeva da bi se pružanje određenih privatnih dobara smatralo prirodnim monopolom. Predlaže se uspostava modela koji poštanske usluge neće tretirati kao prirodni monopol te se zahtijeva prilagodba regulatornog okvira u tu svrhu. Primjerenijom regulacijom ovog tržišta ne bi se stvorili samo uvjeti za očuvanje infrastrukture već bi se omogućilo i unapređenje ukupne ekonomske aktivnosti.

Chou (2014) provodi istraživanje o kvaliteti usluge, povjerenju i lojalnosti potrošača koji koriste usluge kućne dostave u Tajvanu. Kao instrument u primarnom istraživanju korišten je anketni upitnik, a u istom je korišteno modeliranje strukturalnim jednadžbama. Rezultati su pokazali kako kvaliteta usluge i povjerenje pozitivno utječu na lojalnost kupaca, dok kvaliteta usluga ima pozitivan utjecaj na povjerenje kupaca. Provedena je i analiza faktora, a rezultati su pokazali kako ispitanici kao ključnu odrednicu usluge vide faktor pouzdanosti. Podaci o pošiljateljima su analizirani u svrhu oblikovanja grupa pošiljatelja. Rezultati analize pokazali su kako pošiljatelji koji su usmjereni na usluge ostvaruju bolje povjerenje i lojalnost kupaca. Menadžeri mogu povećati 
povjerenje potrošača povećanjem povjerenja istih u usluge dostave kako bi isti koristili ili poticali druge u okolini da koriste usluge kućne dostave.

Lăzărescu (2017) promatra izazove s kojima se susreće tržište poštanskih usluga uslijed procesa globalizacije. Poštanske usluge pojavile su se kako bi zadovoljile komunikacijske potrebe čovjeka u posebnim društvenim odnosima. Zadovoljavanje ovih potreba temelji se na mrežnoj organizaciji koja omogućava prijevoz ili slanje paketa na daljinu. Osnivanje Svjetske poštanske unije omogućilo je poduzećima koordinaciju poštanskih usluga širom svijeta kako bi se postigla globalizacija među prvim poštanskim uredima. Funkcija nacionalnih poštanskih mreža bila je u fokusu državnih tijela koja su stvorila specifičan zakonski okvir koji omogućava njihovu komercijalizaciju te samofinanciranje. Globalizacijske tendencije uzrokovale su i strateške promjene na tržištu poštanskih usluga, što se reflektiralo na potrebu provedbe liberalizacije tržišta. Čimbenici koji utječu na tržište poštanskih usluga dijele se na vanjske i unutarnje. Vanjski čimbenici su omogućili razvoj poštanske mreže, a podrazumijevaju razvoj i poboljšanje sredstava komunikacije, prijevoznih sredstava, razvoj komunikacijskih putova kopnom, morem, zrakom te liberalizaciju poštanske usluge. Unutarnji čimbenici su povećanje i diversifikacija tradicionalne poštanske usluge povećanjem volumena komercijalnih usluga i povećanjem bankovnih transfera (Lăzărescu, 2017).

Heco (2018) istražuje mogućnosti unapređenja koncepta održivog razvoja poštanskog sektora i zaštite okoline u Bosni i Hercegovini s osvrtom na univerzalne poštanske usluge. Obzirom da je poštanska usluga javna funkcija koja je iznimno važna za funkcioniranje društva, od velike je važnosti osigurati unapređenje koncepta održivog razvoja poštanskog sektora. Nacionalna pošta svakako mora redefinirati postojeću poslovnu strategiju, a s druge strane treba se i uskladiti nacionalna regulativa poštanskog tržišta sa Zakonodavstvom Europske unije.

Dwianto i Purnamasari (2018) istražuju utjecaj kvalitete usluge (pouzdanost, odgovornost i sl.) na cjelokupno ili djelomično zadovoljstvo potrošača, a u svrhu utvrđivanja što ima dominantniji utjecaj od kvalitete usluge na zadovoljstvo potrošača prilikom korištenja usluge dostave paketa na primjeru indonezijske pošte u Banjarmasinu. U primarnom istraživanju kao instrument istraživanja je korišten strukturirani podsjetnik za intervju, a koji je proveden nad uzorkom od 100 ispitanika. Rezultati su pokazali kako opipljivost i sigurnost nemaju značajan utjecaj za tumačenje promjena kod ponašanja domaćih potrošača koji koriste usluge poštanskih ureda u Banjarmasinu, dok se pokazalo kako dominantan utjecaj ima odaziv, odnosno, spremnost poduzeća da pruži informacije o isporuci, brzini, kao i mogućnostima dostave paketa te spremnost poduzeća na pomoć u slučaju problema prilikom isporuke.

\section{2 Metodologija istraživanja}

Obzirom na nedovoljan broj istraživanja usluga koje nude paketnih dobavljači, i posebice nedovoljna saznanja o čimbenicima koji utječu na zadovoljstvo mladih korisnika uslugama paketnih dostavljača u Republici Hrvatskoj, upravo je navedeno cilj empirijskog dijela istraživanja. Istraživanje je inspirirano, a sam je instrument istraživanja u velikoj mjeri oblikovan po uzoru na najrecentnija postojeća istraživanja koja obuhvaćaju područje paketne distribucije, među kojima prednjače autori Chou (2014), Seitz et al. (2008) i Li et al. (2006). 
Empirijsko istraživanje provedeno je u rujnu 2018. godine putem online anketnog upitnika dizajniranog u SurveyMonkeyu, a poziv za sudjelovanje u istraživanju zajedno s poveznicom na anketni upitnik: https://www.surveymonkey.com/r/paketni_dostavljaci, proslijeđen je putem društvenih mreža mladim potrošačima koji su bili i ciljna skupina ovog istraživanja. Anketni se upitnik sastojao od 19 pitanja, kojima se ispitivalo:

Ad 1. korištenje usluga paketnih dostavljača u Republici Hrvatskoj

Ad 2. usluge kojih paketnih dostavljača (DHL, DPD, FedEx, GLS, Hrvatska pošta, InTime, Overseas, Tisak, UPS, nekih drugih paketnih dostavljača) u Republici Hrvatskoj su se ispitanici koristili

Ad 3. navođenje pružatelja usluge paketne distribucije s kojima su ispitanici najzadovoljniji

Ad 4. navođenje država iz kojih su ispitanici najčešće naručivali pakete iz inozemstva

Ad 5. vrsta proizvoda koje su ispitanici najčešće naručivali putem paketne dostave

Ad 6. učestalost korištenja usluga paketne dostave

Ad 7. uobičajena visina cijene paketa kojeg ispitanici naručuju

Ad 8. vrsta dostave koju ispitanici koriste kada naručuju paket.

Nadalje, ispitanici su bili zamoljeni da rangiraju važnost sljedećih atributa: poštivanje roka dostave, cijenu, ponudu usluga, standarde poslovanja, naknade, tehnologiju, prepoznatljivost imena, globalno poslovanje/internacionalnost, dostupnost usluge, pouzdanost usluge, potpunost usluge, profesionalizam usluge, prilikom odabira pružatelja usluge paketne distribucije, ocjenama od 1 do 5 , gdje je 1 = najmanje važan atribut, a 5 = najvažniji atribut. Potom su zamoljeni da navedu stupanj slaganja s 30 tvrdnji koje se odnose na pružatelje usluge paketne distribucije, a preuzete su iz postojeće literature i prethodno navedenih istraživanja, pomoću Likertove skale, na ljestvici od 1 do 5 , gdje je 1 = u potpunosti se ne slažem, 2 = ne slažem se, 3 = niti se ne slažem, niti se slažem, 4 = slažem se i 5 = u potpunosti se slažem. Nadalje, ispitanike se pitalo jesu li imali pritužbe prilikom korištenja usluga paketne distribucije i ukoliko jesu, da opišu svoja iskustva. Otvorenim pitanjem bili su zamoljeni da navedu na koji način bi se paketni dostavljači mogli prilagoditi njihovim željama i potrebama u budućnosti. Anketni upitnik završava pitanjima koja obuhvaćaju sociodemografska obilježja ispitanika - spol, dob, stručnu spremu, radni status, regiju u kojoj ispitanici stanuju i osobni mjesečni prihod ispitanika.

\section{3 Rezultati istraživanja}

\subsection{Sociodemografske karakteristike ispitanika}

U istraživanju je sudjelovalo 282 ispitanika, od čega su 166 (59,93 \%) ispitanika bili muškarci, a 111 $(40,07 \%)$ ispitanika su bile žene. Pet ispitanika nije dalo odgovor na pitanje o spolnoj strukturi. Ispitanici su grupirani prema dobi kako slijedi: manje od 18 godina (1,07\%); od 18 do 24 godine (25,98\%), od 25 do 34 godine (34,16\%), od 35 do 44 godine (12,10\%); od 45 do 54 godine (10,68 \%), od 55 do 64 godine (13,17 \%) i više od 65 godina (2,85\%). Obzirom na navedenu dobnu 
strukturu, u tablici 1 se može uočiti kako je mladih ispitanika (mlađi od 35 godina) bilo 177, dok je 118 ispitanika imalo 35 godina ili više.

Tablica 1. Starosna struktura ispitanika

\begin{tabular}{|l|c|c|c|c|}
\hline DOSTAVLJAČ & A SKUPINA & FREKVENCIJA & $\%$ & KUMULATIV \% \\
\hline \multirow{4}{*}{ MLADI } & manje od 18 godina & 3 & 1,00 & 1,00 \\
\cline { 2 - 5 } & 18 do 24 godine & 74 & 25,00 & 26,10 \\
\cline { 2 - 5 } & 25 do 34 godine & 100 & 33,8 & 60,00 \\
\hline \multirow{3}{*}{ STARIJI } & 35 do 44 godine & 36 & 12,20 & 72,20 \\
\cline { 2 - 5 } & 45 do 54 godine & 32 & 10,80 & 83,10 \\
\cline { 2 - 5 } & 55 do 64 godine & 41 & 13,90 & 96,90 \\
\cline { 2 - 5 } & više od 65 godine & 9 & 3,00 & 100,00 \\
\hline & UKUPNO & 295 & 99,70 & \\
\hline
\end{tabular}

Izvor: izrada autora na temelju prikupljenih podataka

S obzirom na stručnu spremu, najveći broj ispitanika, njih čak $56,58 \%(n=159)$ ima završenu višu školu ili fakultet; $28,11 \%$ ispitanika ima završenu srednju stručnu školu ili gimnaziju - 4 godine; a $13,17 \%$ ispitanika ima završen magisterij ili doktorat. Najmanji broj ispitanika koji su sudjelovali u istraživanju su bez stručne spreme ili imaju završenu osnovnu (0,71 \%) ili trogodišnju srednju školu $(1,42 \%)$. Promatra li se radni status ispitanika, uočava se kako je sudjelovalo najviše zaposlenih, u stalnom radnom odnosu (55,43\%), nezaposlenih (15,94\%) i ispitanika koji rade preko studentskog ugovora (13,04\%). Kod ispitivanja o regiji u kojoj ispitanici stanuju, od ukupnog broja ispitanika, njih 153 (54,45\%) odgovorilo je da žive u Dalmaciji, 99 ispitanika živi u Zagrebu i okolici (35,23 \%), 11 ispitanika stanuje u Slavoniji (3,91 \%), osam ispitanika u sjevernoj Hrvatskoj, a po pet u Lici, Kordunu i Banovini te Istri, Primorju i Gorskom Kotaru. Osobni mjesečni prihod ispitanika varira od iznosa manjeg od 1200 kuna sve do više od $9000 \mathrm{kn}$. Dok 63 (22,50\%) ispitanika ima prihode više od 9000 kn, 16,43 \% ispitanika imaju osobne mjesečne prihode od 5501 do 7000 kn, onih koji imaju prihode od 7001 do $9000 \mathrm{kn}$ ima 45 (16,07\%) dok je 42 (15,00\%) ispitanika imalo osobne prihode od 3501 do 5500 kn. Svega 4 ispitanika navelo je da imaju osobni mjesečni prihod do 500 kn, a 40 ispitanika je bez osobnog mjesečnog prihoda.

\subsubsection{Korištenje usluga paketnih dostavljača u Republici Hrvatskoj}

Kako bi se utvrdilo utječe li dob ispitanika na preferencije glede odrednica kvalitete poštanskih usluga, u softverskom programu SPPS isto je testirano. Rezultati provedenog testa potvrdili su utjecaj dobi samo kod tri čimbenika: cijena, dostupnost usluge te brzina pružanja usluge. Stoga su u nastavku prikazani rezultati za cjelokupni uzorak, dok će prilikom analize navedena 3 čimbenika u fokusu biti isključivo mladi korisnici.

Prvo pitanje koje je ispitanicima postavljeno odnosilo se na korištenje usluga paketnih dobavljača u Republici Hrvatskoj, a ispitanicima je dana uputa da navedeno podrazumijeva i primitak paketa iz inozemstva. Većina ispitanika (245; $86,87 \%$ ) odgovorilo je da su koristili usluge paketnih 
dostavljača u Republici Hrvatskoj. Ispitanici koji su izjavili da nikada nisu koristili usluge paketnih dostavljača u Republici Hrvatskoj, njih 37 (13,12 \%), zamoljeni su da odgovore na 13. pitanje u anketnom upitniku kojim su se ispitivali razlozi nekorištenja usluga paketne dostave. U Tablici 2 navedene su usluge paketnih dostavljača koje su ispitanici $(n=245)$ koristili u Republici Hrvatskoj. Ovdje je ispitanicima dana mogućnost odabira višestrukog odgovora.

Tablica 2. Korištenje usluga paketnih dostavljača u Republici Hrvatskoj

\begin{tabular}{|l|l|l|}
\hline DOSTAVLJAČ & $\%$ & $\mathbf{n}$ \\
\hline DHL & $60,00 \%$ & 153 \\
\hline DPD & $16,47 \%$ & 42 \\
\hline FedEx & $18,04 \%$ & 46 \\
\hline GLS & $23,92 \%$ & 61 \\
\hline Hrvatska pošta & $81,18 \%$ & 207 \\
\hline Intime & $4,71 \%$ & 12 \\
\hline Overseas & $47,45 \%$ & 121 \\
\hline Tisak & $38,04 \%$ & 97 \\
\hline UPS & $13,73 \%$ & 35 \\
\hline Ostali paketni dostavljači & $1,18 \%$ & 3 \\
\hline
\end{tabular}

Izvor: izrada autora na temelju prikupljenih podataka

Kao što je vidljivo iz tablice 2, ispitanici najviše koriste usluge Hrvatske pošte (81,18 \%), DHL-a (60,00 \%) i GLS-a (23,92 \%). Na Grafikonu 1 može se uočiti kako su ispitanici najzadovoljniji uslugama DHL-a, a potom uslugama hrvatskog nacionalnog poštanskog operatora (Hrvatska pošta).

Grafikon 1. Zadovoljstvo ispitanika s pružateljem usluga paketne distribucije

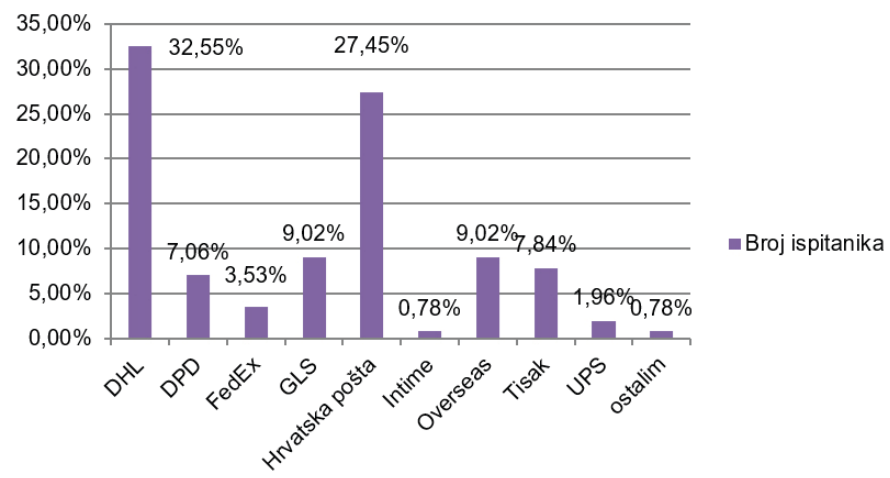

Izvor: primarno istraživanje 
Glede država iz koje su ispitanici najčešće naručivali paket iz inozemstva, naveli su Njemačku, Ujedinjeno Kraljevstvo, Kinu, Englesku, Ameriku, Austriju, Irsku, Francusku, Slovačku, a što svjedoči o velikoj prednosti i pogodnosti usluge transporta i dostave robe koju pružatelji takvih usluga nude potrošačima u premošćivanju velikih geografskih udaljenosti. S obzirom na vrstu proizvoda koje ispitanici najčešće naručuju (Grafikon 2) putem paketne dostave, primat ima tehnička oprema (33,60 \%), slijede odjeća (19,60\%), knjige (16,80\%), modni dodaci i obuća.

Grafikon 2. Vrsta proizvoda koje ispitanici najčešće naručuju putem paketne dostave

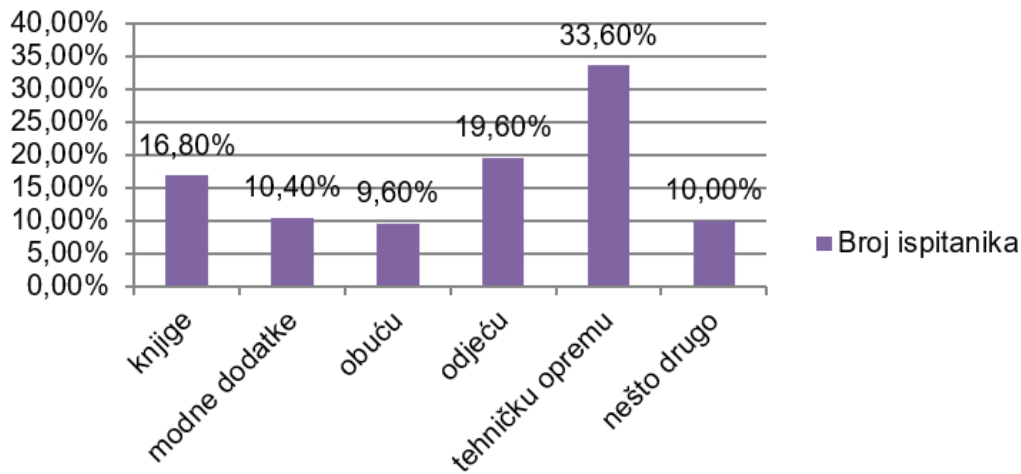

Izvor: primarno istraživanje

U Tablici 3 prikazana je učestalost korištenja usluga paketne dostave. Najčešće se usluge paketne dostave koriste jednom u šest mjeseci (41,34\%) ili jednom mjesečno (34,65\%).

Tablica 3. Učestalost korištenja usluga paketne dostave

\begin{tabular}{|l|c|c|}
\hline Učestalost & $\%$ & $\mathbf{n}$ \\
\hline svaki dan & $0,39 \%$ & 1 \\
\hline jednom do dva puta tjedno & $3,94 \%$ & 10 \\
\hline jednom mjesečno & $34,65 \%$ & 88 \\
\hline jednom u šest mjeseci & $41,34 \%$ & 105 \\
\hline jednom godišnje & $16,93 \%$ & 43 \\
\hline ostalo & $2,76 \%$ & 7 \\
\hline
\end{tabular}

Izvor: primarno istraživanje

Ispitanici su bili upitani koliko uobičajeno iznosi cijena paketa kojeg naručuju. Zanimljivo je da su odgovori ispitanika značajno varirali i kreću se u rasponu od najniže spomenute cijene (50 kn), do najviše cijene u iznosu od 1500 kn. Što se tiče vrste dostave koju ispitanici koriste, najveći broj ispitanika $(65,61 \%)$ navodi standardnu dostavu, potom kombinaciju standardne i ekspres dostave $(24,11 \%)$, a svega $10,28 \%$ ispitanika koristi isključivo ekspres dostavu. 
D. Naletina, M. Damić, L. Meštrović: Zadovoljstvo mladih korisnika uslugama paketnih dostavljača... Zbornik Veleučilišta u Rijeci, Vol. 8 (2020), No. 1, pp. 331-351

Tablica 4. Važnost pojedinih atributa prilikom odabira pružatelja usluge pakete distribucije

\begin{tabular}{|c|c|c|c|c|c|c|c|}
\hline ATRIBUTI & 1 & 2 & 3 & 4 & 5 & $\overline{\mathbf{x}}$ & Rang \\
\hline & n (\%) & n (\%) & n (\%) & n (\%) & n (\%) & n (\%) & \\
\hline poštivanje roka dostave & $62,37 \%$ & $\begin{array}{c}5 \\
1,98 \%\end{array}$ & $\begin{array}{c}21 \\
8,30 \%\end{array}$ & $\begin{array}{c}42 \\
16,60 \%\end{array}$ & $\begin{array}{c}179 \\
70,75 \%\end{array}$ & 4,51 & 2 \\
\hline cijena & $\begin{array}{c}5 \\
1.98 \% \\
\end{array}$ & $\begin{array}{c}13 \\
5,16 \% \\
\end{array}$ & $\begin{array}{c}60 \\
23,81 \% \\
\end{array}$ & $\begin{array}{c}65 \\
25,79 \% \\
\end{array}$ & $\begin{array}{c}109 \\
43,25 \%\end{array}$ & 4,03 & 6 \\
\hline ponuda usluga & $\begin{array}{c}14 \\
5.58 \% \\
\end{array}$ & $\begin{array}{c}13 \\
5,18 \% \\
\end{array}$ & $\begin{array}{c}82 \\
32,67 \% \\
\end{array}$ & 83 & $\begin{array}{c}59 \\
23,51 \% \\
\end{array}$ & 3,64 & 11 \\
\hline standardi poslovanja & $\begin{array}{c}13 \\
5,22 \% \\
\end{array}$ & $\begin{array}{c}13 \\
5,22 \% \\
\end{array}$ & $\begin{array}{c}53 \\
21,29 \% \\
\end{array}$ & $\begin{array}{c}78 \\
33,07 \% \\
\end{array}$ & $\begin{array}{c}92 \\
36,95 \% \\
\end{array}$ & 3,90 & 8 \\
\hline naknade & $\begin{array}{c}9 \\
3,61 \%\end{array}$ & $\begin{array}{c}10 \\
4,02 \%\end{array}$ & $\begin{array}{c}61 \\
24,50 \%\end{array}$ & $\begin{array}{c}63 \\
25,30 \%\end{array}$ & $\begin{array}{c}106 \\
42,57 \%\end{array}$ & 3,99 & 7 \\
\hline tehnologija & $\begin{array}{c}12 \\
4,80 \%\end{array}$ & $\begin{array}{c}16 \\
6,40 \%\end{array}$ & $\begin{array}{c}76 \\
30,40 \%\end{array}$ & $\begin{array}{c}72 \\
28,80 \%\end{array}$ & $\begin{array}{c}74 \\
29,60 \%\end{array}$ & 3,72 & 10 \\
\hline prepoznatljivost imena & $\begin{array}{c}34 \\
13,60 \% \\
\end{array}$ & $\begin{array}{c}40 \\
16,00 \% \\
\end{array}$ & \begin{tabular}{c|}
65 \\
$26,00 \%$ \\
\end{tabular} & $\begin{array}{c}70 \\
28,00 \%\end{array}$ & $\begin{array}{c}41 \\
16,40 \% \\
\end{array}$ & 3,18 & 12 \\
\hline $\begin{array}{l}\text { globalno poslovanje/ } \\
\text { internacionalnost }\end{array}$ & $\begin{array}{c}15 \\
6,02 \% \\
\end{array}$ & $\begin{array}{c}18 \\
7,23 \% \\
\end{array}$ & $\begin{array}{c}60 \\
24,10 \% \\
\end{array}$ & $\begin{array}{c}80 \\
32,13 \% \\
\end{array}$ & $\begin{array}{c}76 \\
30,52 \% \\
\end{array}$ & 3,74 & 9 \\
\hline dostupnost usluge & $\begin{array}{c}7 \\
2,76 \% \\
\end{array}$ & $\begin{array}{c}6 \\
2,36 \% \\
\end{array}$ & $\begin{array}{c}27 \\
10,63 \% \\
\end{array}$ & $\begin{array}{c}65 \\
25,59 \% \\
\end{array}$ & $\begin{array}{c}149 \\
58,66 \% \\
\end{array}$ & 4,35 & 5 \\
\hline pouzdanost usluge & $\begin{array}{c}8 \\
3,16 \%\end{array}$ & $\begin{array}{c}3 \\
1,19 \%\end{array}$ & $\begin{array}{c}14 \\
5,53 \%\end{array}$ & $\begin{array}{c}29 \\
11,46 \%\end{array}$ & $\begin{array}{c}199 \\
78,66 \%\end{array}$ & 4,61 & 1 \\
\hline potpunost usluge & $\begin{array}{c}4 \\
1,59 \% \\
\end{array}$ & $\begin{array}{c}4 \\
1,59 \% \\
\end{array}$ & $\begin{array}{c}29 \\
11,55 \% \\
\end{array}$ & $\begin{array}{c}52 \\
20,72 \% \\
\end{array}$ & $\begin{array}{c}162 \\
64,54 \% \\
\end{array}$ & 4,45 & 3 \\
\hline profesionalizam usluge & $\begin{array}{c}6 \\
2,37 \%\end{array}$ & $\begin{array}{c}6 \\
2,37 \%\end{array}$ & $\begin{array}{c}24 \\
9,49 \%\end{array}$ & $\begin{array}{c}51 \\
20,16 \%\end{array}$ & $\begin{array}{c}166 \\
65,61 \%\end{array}$ & 4,44 & 4 \\
\hline
\end{tabular}

Tablica 4 prikazuje važnost pojedinih atributa prilikom odabira pružatelja usluge paketne distribucije. Atributi su djelomično preuzeti iz postojeće literature (Seitz et al., 2008; Chou, 2014), a djelomično preuzeti i po potrebi modificirani iz preostalih znanstvenih članaka analiziranih u pregledu postojećih istraživanja. Ispitanici su bili zamoljeni da rangiraju koliko su im sljedeći atributi: poštivanje roka dostave, cijena, ponuda usluga, standardi poslovanja, naknade, tehnologija, prepoznatljivost imena, globalno poslovanje, dostupnost usluge, pouzdanost usluge, potpunost usluge i profesionalizam usluge važni kod odabira pružatelja usluge paketne distribucije. Ispitanicima je na prvom mjestu pouzdanost usluge $(\bar{x}=4,61)$, potom poštivanje roka dostave $(\bar{x}=$ $4,51)$, potpunost usluge $(\bar{x}=4,45)$, profesionalizam usluge $(\bar{x}=4,44)$, dostupnost usluge $(\bar{x}=4,35)$, 
cijena $(\bar{x}=4,03)$, naknade $(\bar{x}=3,99)$, standardi poslovanja $(\bar{x}=3,90)$, globalno poslovanje $(\bar{x}=3,74)$, tehnologija $(\bar{x}=3,72)$, ponuda usluga $(\bar{x}=3,64)$ i prepoznatljivost imena $(\bar{x}=3,18)$.

Rezultati provedenog testa nezavisnih uzoraka potvrdili su kako isključivo kod tri čimbenika (cijena, dostupnost usluge te brzina pružanja usluge) dob utječe na preferencije ispitanika. Za navedena tri čimbenika $p$ vrijednost je iznosila, 000 . Rezultati istraživanja ne odstupaju značajnije od postojećih istraživanja danih u pregledu postojeće literature i samo potvrđuju važnost pojedinih obilježja usluge, posebice prilikom paketne distribucije, kao što su pouzdanost usluge, poštivanje roka dostave i ostala neopipljiva obilježja usluga koja su presudna prilikom odabira pružatelja usluge paketne distribucije.

Nadalje, ispitanici su bili zamoljeni da na Likertovoj skali, ocjenama od 1 do 5 ocjene stupanj slaganja s tvrdnjama koje se odnose na pružatelje usluge paketne distribucije. Tvrdnje su se odnosile na ekološku odgovornost pružatelja usluge paketne distribucije, preporuku prijatelja za korištenje pružatelja usluge paketne distribucije, razliku u cijeni ekspresne dostave i standardne dostave, sigurnost paketa, isporučivost paketa u stanju u kojem je paket bio i poslan, usporedbu brzine usluge dostave paketa hrvatskog nacionalnog poštanskog operatora i inozemnih pružatelja usluge distribucije paketa prisutnih na hrvatskom tržištu, zadovoljstvo korisnika cijenom usluge dostave paketa, načinom na koji je paket zapakiran u svrhu zaštite prilikom transporta, radnim vremenom kontaktnog centra kurirskih službi, uslugom dispečera u kontaktnom centru, kvalitetom servisa za praćenje pošiljke, ljubaznošću dostavljača. Navedene su tvrdnje preuzete iz postojeće literature, a djelomično su i modificirane i prilagođene za potrebe provođenja ovoga istraživanja. Analizirajući stupanj slaganja ispitanika s tvrdnjama koje se odnose na pružatelje usluge paketne distribucije, zaključuje se da su ispitanici najzadovoljniji kada njihov paket sretno stigne na odredište $(\bar{x}=3,89)$ i kada pružatelji usluga distribucije vode računa o sigurnosti paketa $(\bar{x}=3,87)$ i da paket bude isporučen u stanju u kojem je i poslan $(\bar{x}=3,85)$. Poražavajući su rezultati koji govore da ispitanici prilikom odabira usluge paketne distribucije, najmanje vode računa o ekološkoj odgovornosti pružatelja usluge $(\bar{x}=2,85)$ te da imaju negativna iskustva s poštovanjem roka dostave od stane hrvatskog nacionalnog poštanskog operatora $(\bar{x}=3,06)$ (vidi Tablica 5 ). 
Tablica 5. Stupanj slaganja ispitanika s tvrdnjama koje se odnose na pružatelje usluge paketne distribucije

\begin{tabular}{|c|c|c|c|c|c|c|}
\hline TVRDNJE & 1 & 2 & 3 & 4 & 5 & $\bar{x}$ \\
\hline & $\mathrm{n}(\%)$ & $\mathrm{n}(\%)$ & $\mathrm{n}(\%)$ & $n(\%)$ & $\mathrm{n}(\%)$ & \\
\hline $\begin{array}{l}\text { Prilikom odabira usluge paketne distribucije, } \\
\text { vodim računa o ekološkoj odgovornosti } \\
\text { pružatelja usluge. }\end{array}$ & $\begin{array}{c}51 \\
20,08 \%\end{array}$ & $\begin{array}{c}43 \\
16,93 \%\end{array}$ & $\begin{array}{c}87 \\
34,25 \%\end{array}$ & $\begin{array}{c}39 \\
15,35 \%\end{array}$ & $\begin{array}{c}34 \\
13,39 \%\end{array}$ & 2,85 \\
\hline $\begin{array}{l}\text { Prilikom odabira usluge paketne distribucije, } \\
\text { koristim pružatelje koje mi predlažu moji } \\
\text { prijatelji. }\end{array}$ & $\begin{array}{c}29 \\
11,46 \%\end{array}$ & $\begin{array}{c}37 \\
14,62 \%\end{array}$ & $\begin{array}{c}67 \\
26,48 \%\end{array}$ & $\begin{array}{c}83 \\
32,81 \%\end{array}$ & $\begin{array}{c}37 \\
14,62 \%\end{array}$ & 3,25 \\
\hline $\begin{array}{l}\text { Ponekad nisam u mogućnosti odabrati } \\
\text { distributera, s obzirom da određena poduzeća } \\
\text { imaju unaprijed dogovorenog pružatelja usluga } \\
\text { s kojim posluju. }\end{array}$ & $\begin{array}{c}15 \\
5,91 \%\end{array}$ & $\begin{array}{c}12 \\
4,72 \%\end{array}$ & $\begin{array}{c}61 \\
24,02 \%\end{array}$ & $\begin{array}{c}73 \\
28,74 \%\end{array}$ & $\begin{array}{c}93 \\
36,61 \%\end{array}$ & 3,85 \\
\hline $\begin{array}{l}\text { Smatram da je previsoka razlika u cijeni } \\
\text { ekspresne dostave i cijeni regularne dostave. }\end{array}$ & $\begin{array}{c}7 \\
2,76 \%\end{array}$ & $\begin{array}{c}13 \\
5,12 \%\end{array}$ & $\begin{array}{c}93 \\
36,61 \%\end{array}$ & $\begin{array}{c}75 \\
29,53 \%\end{array}$ & $\begin{array}{c}66 \\
25,98 \%\end{array}$ & 3,71 \\
\hline $\begin{array}{l}\text { Pružatelji usluge distribucije paketa s kojima sam } \\
\text { do sada imao iskustva, vode računa o sigurnosti } \\
\text { paketa. }\end{array}$ & $\begin{array}{c}4 \\
1,57 \%\end{array}$ & $\begin{array}{c}15 \\
5,91 \%\end{array}$ & $\begin{array}{c}62 \\
24,41 \%\end{array}$ & $\begin{array}{c}101 \\
39,76 \%\end{array}$ & $\begin{array}{c}72 \\
28,35 \%\end{array}$ & 3,87 \\
\hline $\begin{array}{l}\text { Pružatelji usluge distribucije paketa s kojima sam } \\
\text { do sada imao iskustva, vode računa o tome da } \\
\text { paket bude isporučen u stanju u kojem je bio i } \\
\text { poslan. }\end{array}$ & $\begin{array}{c}7 \\
2,77 \%\end{array}$ & $\begin{array}{c}20 \\
7,91 \%\end{array}$ & $\begin{array}{c}52 \\
20,55 \%\end{array}$ & $\begin{array}{c}99 \\
39,13 \%\end{array}$ & $\begin{array}{c}75 \\
29,64 \%\end{array}$ & 3,85 \\
\hline $\begin{array}{l}\text { Mišljenja sam da je kvaliteta usluge dostave } \\
\text { paketa hrvatskog nacionalnog poštanskog } \\
\text { operatora ispod razine kvalitete usluge vodećih } \\
\text { inozemnih pružatelja usluge distribucije paketa } \\
\text { prisutnih na hrvatskom tržištu. }\end{array}$ & $\begin{array}{c}23 \\
9,06 \%\end{array}$ & $\begin{array}{c}33 \\
12,99 \%\end{array}$ & $\begin{array}{c}94 \\
37,01 \%\end{array}$ & $\begin{array}{c}47 \\
18,50 \%\end{array}$ & $\begin{array}{c}57 \\
22,44 \%\end{array}$ & 3,32 \\
\hline $\begin{array}{l}\text { Mišljenja sam da je brzina usluge dostave paketa } \\
\text { hrvatskog nacionalnog poštanskog operatora } \\
\text { ispod brzine usluge dostave vodećih inozemnih } \\
\text { pružatelja usluge distribucije paketa prisutnih na } \\
\text { hrvatskom tržištu. }\end{array}$ & $\begin{array}{c}20 \\
7,87 \%\end{array}$ & $\begin{array}{c}35 \\
13,78 \%\end{array}$ & $\begin{array}{c}82 \\
32,28 \%\end{array}$ & $\begin{array}{c}55 \\
21,65 \%\end{array}$ & $\begin{array}{c}62 \\
24,41 \%\end{array}$ & 3,41 \\
\hline $\begin{array}{l}\text { Imam negativna iskustva s poštivanjem roka } \\
\text { dostave od strane hrvatskog nacionalnog } \\
\text { poštanskog operatora. }\end{array}$ & $\begin{array}{c}38 \\
14,96 \%\end{array}$ & $\begin{array}{c}58 \\
22,83 \%\end{array}$ & $\begin{array}{c}60 \\
23,62 \%\end{array}$ & $\begin{array}{c}48 \\
18,90 \%\end{array}$ & $\begin{array}{c}50 \\
19,69 \%\end{array}$ & 3,06 \\
\hline $\begin{array}{l}\text { Zadovoljan/-na sam cijenom usluge dostave } \\
\text { paketa. }\end{array}$ & $\begin{array}{c}6 \\
2,37 \%\end{array}$ & $\begin{array}{c}29 \\
11,46 \%\end{array}$ & $\begin{array}{c}109 \\
43,08 \%\end{array}$ & $\begin{array}{c}79 \\
31,23 \%\end{array}$ & $\begin{array}{c}30 \\
11,86 \%\end{array}$ & 3,39 \\
\hline $\begin{array}{l}\text { Zadovoljan/-na sam načinom na koji je moj } \\
\text { paket zapakiran u svrhu zaštite prilikom } \\
\text { transporta. }\end{array}$ & $\begin{array}{c}5 \\
1,98 \%\end{array}$ & $\begin{array}{c}14 \\
5,53 \%\end{array}$ & $\begin{array}{c}76 \\
30,04 \%\end{array}$ & $\begin{array}{c}100 \\
39,53 \%\end{array}$ & $\begin{array}{c}58 \\
22,92 \%\end{array}$ & 3,76 \\
\hline $\begin{array}{l}\text { Zadovoljan/-na sam radnim vremenom } \\
\text { kontaktnog centra kurirskih službi. }\end{array}$ & $\begin{array}{c}20 \\
7,87 \%\end{array}$ & $\begin{array}{c}38 \\
14,96 \%\end{array}$ & $\begin{array}{c}92 \\
36,22 \%\end{array}$ & $\begin{array}{c}78 \\
30,71 \%\end{array}$ & $\begin{array}{c}26 \\
10,24 \%\end{array}$ & 3,2 \\
\hline
\end{tabular}


D. Naletina, M. Damić, L. Meštrović: Zadovoljstvo mladih korisnika uslugama paketnih dostavljača... Zbornik Veleučilišta u Rijeci, Vol. 8 (2020), No. 1, pp. 331-351

\begin{tabular}{|c|c|c|c|c|c|c|}
\hline $\begin{array}{l}\text { Zadovoljan/-na sam uslugom dispečera u } \\
\text { kontaktnom centru. }\end{array}$ & $\begin{array}{c}18 \\
7,09 \%\end{array}$ & $\begin{array}{c}27 \\
10,63 \%\end{array}$ & $\begin{array}{c}103 \\
40,55 \%\end{array}$ & $\begin{array}{c}78 \\
30,71 \%\end{array}$ & $\begin{array}{c}28 \\
11,02 \%\end{array}$ & 3,28 \\
\hline $\begin{array}{l}\text { Dispečer u kontaktnom centru posjeduje } \\
\text { adekvatna znanja i pomaže mi u rješavanju } \\
\text { problema. }\end{array}$ & $\begin{array}{c}19 \\
7,48 \%\end{array}$ & $\begin{array}{c}28 \\
11,02 \%\end{array}$ & $\begin{array}{c}105 \\
41,34 \%\end{array}$ & $\begin{array}{c}75 \\
29,53 \%\end{array}$ & $\begin{array}{c}27 \\
10,63 \%\end{array}$ & 3,25 \\
\hline $\begin{array}{l}\text { Nezadovoljan/-na sam informacijama o cijeni } \\
\text { dostave, uvjetima dostave koji su raspoloživi na } \\
\text { web stranici pružatelja usluge. }\end{array}$ & $\begin{array}{c}23 \\
9,06 \%\end{array}$ & $\begin{array}{c}37 \\
14,57 \%\end{array}$ & $\begin{array}{c}114 \\
44,88 \%\end{array}$ & $\begin{array}{c}49 \\
19,29 \%\end{array}$ & $\begin{array}{c}31 \\
12,20 \%\end{array}$ & 3,11 \\
\hline $\begin{array}{l}\text { Zadovoljan/-na sam informacijama o cijeni } \\
\text { dostave i uvjetima dostave kojima raspolažu } \\
\text { dispečeri u kontaktnom centru. }\end{array}$ & $\begin{array}{c}13 \\
5,12 \%\end{array}$ & $\begin{array}{c}19 \\
7,48 \%\end{array}$ & $\begin{array}{c}121 \\
47,64 \%\end{array}$ & $\begin{array}{c}72 \\
58,35 \%\end{array}$ & $\begin{array}{c}29 \\
11,42 \%\end{array}$ & 3,33 \\
\hline $\begin{array}{l}\text { Zadovoljan/-na sam kvalitetom servisa za } \\
\text { praćenje pošiljke. }\end{array}$ & $\begin{array}{c}17 \\
6,72 \%\end{array}$ & $\begin{array}{c}22 \\
8,70 \%\end{array}$ & $\begin{array}{c}76 \\
30,04 \%\end{array}$ & $\begin{array}{c}90 \\
35,57 \%\end{array}$ & $\begin{array}{c}48 \\
18,97 \%\end{array}$ & 3,51 \\
\hline $\begin{array}{l}\text { Zadovoljan/-na sam uslugama dobivanja poruka } \\
\text { na svoj mobilni telefon i e-mail u svezi kretanja } \\
\text { pošiljke. }\end{array}$ & $\begin{array}{c}13 \\
5,18 \%\end{array}$ & $\begin{array}{c}25 \\
9,96 \%\end{array}$ & $\begin{array}{c}68 \\
27,09 \%\end{array}$ & $\begin{array}{c}85 \\
33,86 \%\end{array}$ & $\begin{array}{c}60 \\
23,90 \%\end{array}$ & 3,61 \\
\hline $\begin{array}{l}\text { Zadovoljan/-na sam preciznošću specificiranja } \\
\text { dolaska dostavljača paketa na moju adresu. }\end{array}$ & $\begin{array}{c}8 \\
3,20 \%\end{array}$ & $\begin{array}{c}35 \\
14,00 \%\end{array}$ & $\begin{array}{c}62 \\
24,80 \%\end{array}$ & $\begin{array}{c}94 \\
37,60 \%\end{array}$ & $\begin{array}{c}51 \\
20,40 \%\end{array}$ & 3,58 \\
\hline $\begin{array}{l}\text { Nezadovoljan/-na sam vremenom čekanja do } \\
\text { javljanja dispečera u kontaktnom centru. }\end{array}$ & $\begin{array}{c}14 \\
5,65 \%\end{array}$ & $\begin{array}{c}28 \\
11,29 \%\end{array}$ & $\begin{array}{c}111 \\
44,76 \%\end{array}$ & $\begin{array}{c}53 \\
21,37 \%\end{array}$ & $\begin{array}{c}42 \\
16,94 \%\end{array}$ & 3,33 \\
\hline $\begin{array}{l}\text { Zadovoljan/-na sam brzinom rješavanja } \\
\text { problema s dostavom moje pošiljke. }\end{array}$ & $\begin{array}{c}18 \\
7,62 \%\end{array}$ & $\begin{array}{c}27 \\
10,89 \%\end{array}$ & $\begin{array}{c}111 \\
44,76 \%\end{array}$ & $\begin{array}{c}66 \\
26,61 \%\end{array}$ & $\begin{array}{c}26 \\
10,48 \%\end{array}$ & 3,22 \\
\hline $\begin{array}{l}\text { Zadovoljan/-na sam korištenjem web stranice } \\
\text { pružatelja usluge za prijavu problema. }\end{array}$ & $\begin{array}{c}1 \\
5,65 \%\end{array}$ & $\begin{array}{c}26 \\
10,48 \%\end{array}$ & $\begin{array}{c}109 \\
43,95 \%\end{array}$ & $\begin{array}{c}71 \\
28,63 \%\end{array}$ & $\begin{array}{c}28 \\
11,29 \%\end{array}$ & 3,29 \\
\hline $\begin{array}{l}\text { Do sada se nisam susreo s gubitkom mog } \\
\text { paketa. }\end{array}$ & $\begin{array}{c}30 \\
11,95 \%\end{array}$ & $\begin{array}{c}22 \\
8,76 \% \\
\end{array}$ & $\begin{array}{c}24 \\
9,56 \% \\
\end{array}$ & $\begin{array}{c}45 \\
17,93 \% \\
\end{array}$ & $\begin{array}{c}130 \\
51,79 \% \\
\end{array}$ & 3,89 \\
\hline $\begin{array}{l}\text { Zadovoljan/-na sam brzinom kojom je } \\
\text { dostavljač došao preuzeti moj paket za otpremu. }\end{array}$ & $\begin{array}{c}5 \\
2,04 \% \\
\end{array}$ & $\begin{array}{c}18 \\
7,35 \% \\
\end{array}$ & $\begin{array}{c}95 \\
38,78 \% \\
\end{array}$ & $\begin{array}{c}80 \\
32,65 \% \\
\end{array}$ & $\begin{array}{c}47 \\
19,18 \% \\
\end{array}$ & 3,60 \\
\hline Paketi koje sam slao nikada se nisu oštetili. & $\begin{array}{l}6 \\
2,43 \% \\
\end{array}$ & $\begin{array}{l}20 \\
8,10 \% \\
\end{array}$ & $\begin{array}{l}69 \\
27,94 \% \\
\end{array}$ & $\begin{array}{l}67 \\
27,13 \% \\
\end{array}$ & $\begin{array}{l}85 \\
34,41 \% \\
\end{array}$ & 3,83 \\
\hline $\begin{array}{l}\text { Paketi koje sam slao dostavljeni su u dogovoreno } \\
\text { vrijeme. }\end{array}$ & $\begin{array}{c}5 \\
2,02 \%\end{array}$ & $\begin{array}{c}19 \\
7,66 \%\end{array}$ & $\begin{array}{c}81 \\
32,66 \%\end{array}$ & $\begin{array}{c}82 \\
33,06 \%\end{array}$ & $\begin{array}{c}61 \\
24,60 \%\end{array}$ & 3,71 \\
\hline $\begin{array}{l}\text { Kontaktni centar poduzeća za distribuciju } \\
\text { paketa pružio mi je pomoć od početka, pa do } \\
\text { kraja zaključivanja procesa slanja paketa. }\end{array}$ & $\begin{array}{c}13 \\
5,26 \%\end{array}$ & $\begin{array}{c}14 \\
5,67 \%\end{array}$ & $\begin{array}{c}104 \\
42,11 \%\end{array}$ & $\begin{array}{c}82 \\
33,20 \%\end{array}$ & $\begin{array}{c}34 \\
13,77 \%\end{array}$ & 3,45 \\
\hline Zadovoljan/-na sam ljubaznošću dostavljača. & $\begin{array}{c}8 \\
3,23 \% \\
\end{array}$ & $\begin{array}{c}13 \\
5,24 \%\end{array}$ & $\begin{array}{c}71 \\
28,63 \%\end{array}$ & $\begin{array}{c}91 \\
36,69 \%\end{array}$ & $\begin{array}{c}65 \\
26,21 \%\end{array}$ & 3,77 \\
\hline $\begin{array}{l}\text { Zadovoljan/-na sam kvalitetom cjelokupne } \\
\text { usluge poduzeća za distribuciju paketa. }\end{array}$ & $\begin{array}{c}5 \\
1,99 \% \\
\end{array}$ & $\begin{array}{c}14 \\
5,58 \%\end{array}$ & $\begin{array}{c}78 \\
31,08 \%\end{array}$ & $\begin{array}{c}105 \\
41,83 \%\end{array}$ & $\begin{array}{c}49 \\
19,52 \%\end{array}$ & 3,71 \\
\hline $\begin{array}{l}\text { Usluga paketnog dostavljača bila je u skladu sa } \\
\text { očekivanjima. }\end{array}$ & $\begin{array}{c}4 \\
1,60 \%\end{array}$ & $\begin{array}{c}13 \\
5,20 \%\end{array}$ & $\begin{array}{c}67 \\
26,80 \%\end{array}$ & $\begin{array}{c}110 \\
44,00 \%\end{array}$ & $\begin{array}{c}56 \\
22,40 \%\end{array}$ & 3,80 \\
\hline
\end{tabular}

Izvor: primarno istraživanje 
Tablica 6. Latentne dimenzije kvalitete usluga

\begin{tabular}{|l|c|}
\hline ODREDNICE DIMENZIJA & Opterećenje faktora \\
\hline $\begin{array}{l}\text { Dispečer u kontaktnom centru posjeduje adekvatna znanja i pomaže mi u rješavanju } \\
\text { problema. }\end{array}$ &, 681 \\
\hline Zadovoljan/-na sam kvalitetom servisa za praćenje pošiljke. &, 682 \\
\hline $\begin{array}{l}\text { Zadovoljan/-na sam uslugama dobivanja poruka na svoj mobilni telefon i e-mail u svezi } \\
\text { kretanja pošiljke. }\end{array}$ &, 686 \\
\hline Zadovoljan/-na sam brzinom rješavanja problema s dostavom moje pošiljke. &, 689 \\
\hline $\begin{array}{l}\text { Kontaktni centar poduzeća za distribuciju paketa pružio mi je pomoć od početka, pa do } \\
\text { kraja zaključivanja procesa slanja paketa. }\end{array}$ &, 727 \\
\hline Zadovoljan/-na sam kvalitetom cjelokupne usluge poduzeća za distribuciju paketa. &, 729 \\
\hline cijena &, 501 \\
\hline visina naknada &, 567 \\
\hline dostupnost usluge &, 668 \\
\hline pouzdanost usluge &, 567 \\
\hline potpunost usluge &, 562 \\
\hline profesionalizam usluge &, 576 \\
\hline $\begin{array}{l}\text { Mišljenja sam da je kvaliteta usluge dostave paketa hrvatskog nacionalnog poštanskog } \\
\text { operatera ispod razine kvalitete usluge vodećih inozemnih pružatelja usluge distribucije } \\
\text { paketa prisutnih na hrvatskom tržištu. }\end{array}$ &, 478 \\
\hline $\begin{array}{l}\text { Mišljenja sam da je brzina usluge dostave paketa hrvatskog nacionalnog poštanskog } \\
\text { operatera ispod brzine usluge dostave vodećih inozemnih pružatelja usluge distribucije } \\
\text { paketa prisutnih na hrvatskom tržištu. }\end{array}$ &, 536 \\
\hline $\begin{array}{l}\text { Imam negativna iskustva s poštivanjem roka dostave od strane hrvatskog nacionalnog } \\
\text { poštanskog operatera. }\end{array}$ &, 488 \\
\hline $\begin{array}{l}\text { Nezadovoljan/-na sam informacijama o cijeni dostave, uvjetima dostave koji su raspoloživi } \\
\text { na web stranici pružatelja usluge. }\end{array}$ &, 447 \\
\hline ponuda usluga &, 304 \\
\hline $\begin{array}{l}\text { Prilikom odabira usluge paketne distribucije, vodim računa o ekološkoj odgovornosti } \\
\text { pružatelja usluge. }\end{array}$ &, 309 \\
\hline $\begin{array}{l}\text { Ponekad nisam u mogućnosti odabrati distributera, s obzirom da određena poduzeća imaju } \\
\text { unaprijed dogovorenog pružatelja usluga s kojim posluju. }\end{array}$ \\
\hline
\end{tabular}

Izvor: primarno istraživanje

U svrhu utvrđivanja latentnih dimenzija kvalitete usluge na tržištu paketne distribucije identificirane su latentne dimenzije prikazane u Tablici 6 . $U$ istoj se uočava kako su odrednice prve dimenzije determinirane znanjem i kvalitetom kako dispečera u kontaktnom centru tako i kvalitetom drugih pratećih usluga koje utječu na ocjenu cjelokupnog zadovoljstva kvalitetom usluge. Analizom druge dimenzije evidentno je kako je kvaliteta usluge na ovom tržištu determinirana različitim čimbenicima koji utječu na istu. U sklopu treće dimenzije uočava se kako je stav ispitanika da 
je kvaliteta, ali i brzina usluge hrvatskog nacionalnog poštanskog operatera na nižoj razini od inozemnih pružatelja iste usluge.

Ispitanici su bili zamoljeni da navedu jesu li imali pritužbe prilikom korištenja usluga paketne distribucije. Čak 87,40 \% ispitanika navodi da nisu imali pritužbe, dok je $12,60 \%$ ispitanika imalo pritužbe prilikom korištenja usluga paketne distribucije. Ispitanici koji su imali pritužbe prilikom korištenja usluga paketne distribucije naveli su svoja iskustva. Neka od navedenih su: "Nepravovremena dostava te nepravovremene obavijesti" , „kašnjenje isporuka", „Ostave potvrdu o pošiljci iako se ista može dostaviti",,ne dostavljaju pošiljku na vrata već samo ostave obavijest o pošiljci", „Primio sam obavijest da je bio pokusaj dostave a da nikoga nije bilo na adresi, iako sam u vremenu dostave bio kod kuće. Znači da nitko nije niti pozvonio nego je ostavio obavijest"; „Oštećenje robe pa loša usluga povodom toga; Ostavim kontakt broj mobitela, ali ne žele nazvat prije uručenja pošiljke". Prilikom pitanja o načinu na koji bi se paketni dostavljači mogli prilagoditi željama i potrebama ispitanika u budućnosti, ispitanici navode: bolju organiziranost i dostupnost informacija, brzinu i sigurnost dostave pošiljaka, modernizaciju, profesionalizam.

Ispitanici koji su naveli da ne koriste usluge paketnih dostavljača u Republici Hrvatskoj, kao razloge navode sljedeće: kašnjenje isporuke, nepouzdanost dostave, nepovjerenje u kupovinu putem Interneta, nepostojanje potrebe za takvom vrstom usluge, nekvalitetnu uslugu paketnih dostavljača, dodatno naplaćivanje unatoč plaćenoj poštarini, nepouzdanost, nepovjerenje u korištenje usluga paketnih dostavljača, sporu dostavu i velike naknade.

Pouzdanost usluge i poštivanje roka dostave pokazali su se kao najvažniji atributi koje trebaju zadovoljavati pružatelji usluga. Mladi su korisnici iskazali najviše zadovoljstvo uslugama pružatelja paketne dostave kada njihov paket sretno stigne na odredište i kada pružatelji usluga distribucije vode računa o sigurnosti paketa, te da je isti isporučen u stanju u kojem je i poslan.

\subsection{Ograničenja i preporuke za buduća istraživanja}

Provedeno istraživanje o zadovoljstvu mladih korisnika uslugama paketnih dostavljača u Republici Hrvatskoj ima svoja ograničenja. Kako ne postoje dovoljna saznanja u znanstvenoj literaturi i obzirom na to da je područje paketne dostave nedovoljno istraženo među mladim korisnicima, uistinu je teško komparirati rezultate provedenoga istraživanja s ostalim istraživanjima u području korištenja usluga paketnih dostavljača.

U ovom se radu ispitivalo općenito zadovoljstvo mladih korisnika uslugama paketne distribucije i pružatelja usluga paketne distribucije. $U$ budućnosti bi se istraživački fokus trebao usmjeriti i na detaljnu analizu proizvoda koji se dostavljaju koristeći usluge pojedinih pružatelja usluga.

Osim istraživanja provedenog među potrošačima, po uzoru na svjetska istraživanja, predlaže se u budućnosti istraživački fokus usmjeriti i na poslovne korisnike usluga paketne distribucije. Zanimljivo bi bilo istražiti i percepcije pružatelja usluge paketne distribucije, po uzoru na Seitz et al. (2008). Ovo istraživanje, prvo takve vrste i opsega u Hrvatskoj, može pomoći u sistematizaciji postojećih znanja i unapređenju rada i ponude usluga paketnih dostavljača u Republici Hrvatskoj, na opće zadovoljstvo korisnika navedenih usluga. 


\section{ZAKLJUČAK}

Uslijed završetka liberalizacijskih procesa poštanskih tržišta u zemljama članicama, te kontinuiranog rasta online kupovine, potreba za paketnom dostavom sve je veća. Uslijed tehnološkog napretka i ranije navedenih procesa, mijenja se i ponašanje korisnika, ali i njihova očekivanja glede kvalitete te brzine usluge. Raste i konkurencija na ovom tržištu te poduzeća nastoje, s jedne strane minimizirati troškove, a s druge strane pružiti veću kvalitetu usluge kako bi u konačnici osigurali zadovoljstvo svih sudionika u procesu.

Za potrebe rada provedeno je primarno istraživanje kojim se ispitivalo zadovoljstvo korisnika pružateljima usluga paketne dostave. Rezultati istraživanja upućuju na frekventno korištenje usluga paketne dostave inozemnog pružatelja ( $\mathrm{DHL})$, kao i domaćeg pružatelja usluga poštanske dostave (Hrvatska pošta). Među najznačajnijim rezultatima istraživanja ističe se pouzdanost usluge i poštivanje roka dostave, a koji su se pokazali kao najvažniji atributi koje trebaju zadovoljavati pružatelji usluga. No, bitno je istaknuti kako se dob ispitanika pokazala značajnom samo za tri čimbenika: cijena, dostupnost usluge te brzina pružanja usluge. Mladi korisnici najviše preferiraju da njihov paket sretno stigne na odredište i da je pri tome isti došao u stanju u kojem je poslan. Najmanje važnim pokazala se prepoznatljivost imena poduzeća koje vrši dostavu paketa. Zabrinjavajuće je što ispitanici najmanje vode računa o ekološkoj odgovornosti pružatelja usluge.

Rezultati provedenog istraživanja mogu uvelike pomoći u sistematizaciji postojećih znanja i unapređenju rada i ponude usluga paketnih dostavljača u Republici Hrvatskoj, a na opće zadovoljstvo korisnika navedenih usluga. Obzirom da se u ovom radu ispitivalo općenito zadovoljstvo korisnika uslugama paketne distribucije i pružatelja usluga paketne distribucije, u budućnosti bi se istraživački fokus trebao usmjeriti i na detaljnu analizu proizvoda koji se dostavljaju koristeći usluge pojedinih pružatelja usluga. Također, trebalo bi i utvrditi vezu između rasta online kupovine te lojalnosti korisnika pojedinom pružatelju poštanskih usluga. Obzirom kako na ovom tržištu usluge pružaju kako domaća tako i inozemna poduzeća, u budućim istraživanjima trebalo bi analizirati razliku između ključnih odrednica kvalitete usluge između istih.

\section{LITERATURA}

Andrijanić, I. (1999) Vanjska trgovina: Kako poslovati s inozemstvom. Zagreb: Mikrorad

Bendeković, J., Batarelo, T. (2009) "Modeli poslovnih strategija međunarodne paketne distribucije", Poslovna izvrsnost, 3(2), str. 79-98

Chou, P. F. (2014) "An evaluation of service quality, trust, and customer loyalty in home-delivery services", International Journal of Research in Socail Science, 3(8), str. 99-108.

Dobrodolac, M., Ralević, P. (2013) "Predlog novog koncepta univerzalne poštanske usluge u Republici Srbiji”, XXXI Simpozijum o novim tehnologijama u poštanskom i telekomunikacionom saobraćaju - PosTel 2013, Beograd, str. 204-212, http://postel.sf.bg.ac.rs/simpozijumi/POSTEL2013/RADOVI\%20PDF/Postanski\%20saobracaj,\%20 mreze\%20i\%20servisi/10.\%20Dobrodolac,\%20Ralevic,\%20Stanivukovic.pdf (13.10.2019.)

Dujak, D. (2012) “Upravljanje opskrbnim lancem od strane maloprodaje kroz centralnu distribuciju” U: Segetlija, Z. et al. (Ur.) Poslovna logistika u suvremenom menadžmentu, Osijek: Ekonomski fakultet u Osijeku, str. 47-59

Dwianto, A. S., Purnamasari, P. (2018) "Analysis the influence of service quality on customer satisfaction of domestic postal parcels at Kantor Pos Banjarmasin", Proceedings International Seminar On Accounting for Society, International 
Seminar on Accounting for Society, Pamulang: Faculty of Economy, 1(1), http://openjournal.unpam.ac.id/index. php/Proceedings/article/view/1810/1508 (13.10.2019.)

Finnish Transport and Communications Agency (25.06.2019.) Parcel volumes continued strong growth - letter, newspaper and magazine deliveries declined, https://www.traficom.fi/en/news/parcel-volumes-continued-stronggrowth-letter-newspaper-and-magazine-deliveries-declined (22.11.2019.)

Gligorić, L., Đumić, S. (2013) "Elementi netržišnog poslovnog okruženja na tržǐ̌tu poštanskih usluga u Srbiji", XXXI Simpozijum o novim tehnologijama u poštanskom i telekomunikacionom saobraćaju - PosTel 2013, Beograd, str. 171-182, http://postel.sf.bg.ac.rs/simpozijumi/POSTEL2013/RADOVI\%20PDF/Postanski\%20saobracaj,\%20 mreze\%20i\%20servisi/7.\%20Gligoric,\%20Djumic.pdf (17.10.2019.)

Gligorić, L., Đumić, S. (2013) 〈〉Elementi netržišnog poslovnog okruženja na tržištu poštanskih usluga u Srbiji〉», XXXI Simpozijum o novim tehnologijama u poštanskom i telekomunikacionom saobraćaju - PosTel 2013, Beograd, 03.-04.12.2013., str. 171-182, http://postel.sf.bg.ac.rs/simpozijumi/POSTEL2013/RADOVI\%20PDF/Postanski\%20 saobracaj,\%20mreze\%20i\%20servisi/7.\%20Gligoric,\%20Djumic.pdf (07.09.2018.)

Heco, S. (2018) "Unapređenje koncepta održivog razvoja poštanskog sektora i zaštite okoline sa osvrtom na univerzalne poštanske usluge", Zbornik radova 5. Konferencija „Održavanje - Maintenance 2018", Zenica, 10.-12.05.2018., str. 329334, http://www.odrzavanje.unze.ba/zbornici/2018/045-018-045.pdf (06.09.2018.)

Hillebrand, A. et al. (2016) Technology and change in postal services - impacts on consumers. Bad Honnef: WIK Consult and ITA Consulting

Jackson, P. (01.05.2008.) We need a new business model for the postal market. Post\&Parcel, https://postandparcel. info/24446/news/we-need-a-new-business-model-for-the-postal-market/ (16.08.2018.)

Kollara, N. H. (2017) Digital transformation, business models and the postal industry, doktorski rad, Lausanne: Ecole polytechnique fédérale de Lausanne

Kristensen, K., Martensen, A., Gronholdt, L. (2000) "Customer satisfaction measurement at post Denmark: results of application of the European customer satisfaction index methodology", Total Quality Management, 11(7), str. 10071015. https://doi.org/10.1080/09544120050135533

Kujačić, M., Šarac, D., Jovanović, B. (2009) "Model održivosti univerzalnog poštanskog servisa", XXVII Simpozijum o novim tehnologijama u poštanskom i telekomunikacionom saobraćaju - PosTel 2009, Beograd, str. 3-13, http:// postel.sf.bg.ac.rs/simpozijumi/POSTEL2009/RADOVI\%20PDF/Uvodno\%20izgaganje/M.\%20Kujacic,\%20D.\%20 Sarac,\%20B.Jovanovic.pdf (06.09.2018.)

Lăzărescu, C. (2017) "The Postal Market - a New Economic Challenge in the Context of Globalization", Journal of Humanistic and Social Studies, br. 1, str. 187-196

Li, B. et al. (2006) "A comparison study of customer satisfaction between the UPS and FedEx: an empirical study among university customers", Industrial Management \& Data Systems, 106(2), str. 182-199. https://doi. org/10.1108/02635570610649844

Liu, J., Wen, Y. (2012) Study of Competitiveness: A Case Study of DHL. University of Gavle. Department of Business and Economic studies, http://www.diva-portal.org/smash/get/diva2:545580/FULLTEXT02.pdf (04.09.2018.)

Ministarstvo mora, prometa i infrastrukture (N/A) "Propisi”, http://www.mppi.hr/default.aspx?id=639 (05.07.2018.)

Narodne novine (2015) Zakon o izmjenama i dopunama Zakona o poštanskim uslugama, Zagreb: Narodne novine d.d., br. 78

Peković, O., Tričković, I. (2010) "Modeliranje optimalnog rasporeda jedinica poštanske mreže u cilju poboljšanja logističkih performansi poštanskih sistema", XXVIII Simpozijum o novim tehnologijama u poštanskom i telekomunikacionom saobraćaju - PosTel 2010, Beograd, http://postel.sf.bg.ac.rs/simpozijumi/POSTEL2010/RADOVl\%20PDF/ Postanske\%20tehnologije\%20i\%20elektronsko\%20poslovanje/7.\%20O.Pekovic\%20l.Trickovic.pdf (07.09.2018.)

Seitz, V., Razzouk, N. and Williams, S. L. (2008) "Small Package Transportation Companies: An Exploratory Analysis", Review of Economic and Business Studies, br. 2, str. 77-92. 
D. Naletina, M. Damić, L. Meštrović: Zadovoljstvo mladih korisnika uslugama paketnih dostavljača...

Zbornik Veleučilišta u Rijeci, Vol. 8 (2020), No. 1, pp. 331-351

Šarac, D., Jovanović, B. (2012). 〈>Procena kvaliteta poštanskih usluga 〉, XXX Simpozijum o novim tehnologijama u poštanskom i telekomunikacionom saobraćaju - PosTel 2012, Beograd, 04.-05.12.2012., str. 193-200, http://postel. sf.bg.ac.rs/simpozijumi/POSTEL2012/RADOVI\%20PDF/Postanski\%20saobracaj,\%20mreze\%20i\%20servisi/10.\%20 D.\%20Sarac,\%20B.\%20Jovanovi-\%87.pdf (08.09.2018.)

Vakulenko, Y., Hellström, D., Hjort, K. (2018) "What's in the parcel locker? Exploring customer value in e-commerce last mile delivery”, Journal of Business Research, Vol. 88(July), str. 421-427. https://doi.org/10.1016/j.jbusres.2017.11.033 


\title{
SATISFACTION OF THE YOUNG USERS WITH THE PARCEL DELIVERY SERVICES IN CROATIA
}

\author{
Dora Naletina \\ PhD, Assistant Professor, Faculty of Economics and Business, J. F. Kennedy 6, 10000 Zagreb, Croatia; \\ e-mail: dora.naletina@efzg.hr
}

Mate Damić

PhD, Assistant Professor, Faculty of Economics and Business, J. F. Kennedy 6, 10000 Zagreb, Croatia; e-mail:mdamic@efzg.hr

\section{Luka Meštović}

Mag. oec., PBZ Plc., Radnička 45, 10000 Zagreb, Croatia; e-mail: luka.mestrovic@yahoo.com

\section{SUMMARY}

In the last years, the role of parcel delivery in urban areas has been continuously growing, first and foremost because of the intense importance online commerce is gaining. This is also true of the Croatian market. With the Croatian accession to the European Union, postal services market has liberalized which has created suitable preconditions for the existing services, growth of competition and more packages to be delivered. Almost all world-renown service providers are present on the Croatian parcel distribution market. Bearing in mind that mostly younger population uses information technologies, and therein shop online, their satisfaction with the services provided by the parcel delivery companies in Croatia should be investigated. Therefore, the purpose of this research paper is, based on the primary research, to explore how well young users are satisfied with the package delivery services in Croatia. Reliability and punctuality have been confirmed as the most significant factors that determine the level of satisfaction of the young users with the quality of the overall service. The research also suggests that recognition of the company's name is the least important element. Companies that operate on this market have to improve information availability, work on providing safe and timely delivery and invest in further modernization.

Key words: Croatia, young consumers, parcel consignment, parcel delivery 
